\title{
A case of rare metabolic acidosis related to sorafenib therapy
}

\section{Sorafenib tedavisine bağlı nadir bir metabolik asidoz olgusu}

\author{
๑Muharrem Bayrak, ĐKenan Çadırcı \\ ${ }^{1}$ Health Sciences University, Erzurum Regional Training and Research Hospital, Department of Internal Medicine, Erzurum, Turkey
}

Cite this article as / Bu makaleye atıf için: Bayrak M, Çadırcı K. PA case of rare metabolic acidosis related to sorafenib therapy. Anatolian Curr Med J 2020; 2(4): 159-161.

\begin{abstract}
A 76-year-old female patient was followed up in the oncology clinic with a diagnosis of metastatic papillary thyroid carcinoma. Treatment with sorafenib, a vascular endothelial growth factor receptor (VEGFR) inhibitor, was started. Fifteen days after beginning treatment, the patient was admitted to the emergency department due to newly developed weakness, fatigue and impaired consciousness. The arterial blood gas examination of the patient revealed metabolic acidosis and the patient was hospitalized in the internal medicine clinic. Sorafenib therapy was discontinued, followed by administration of intravenous fluid and sodium bicarbonate therapies. Urinary output and blood gas were closely monitored. Additionally, anti-acidosis tablet $(2000 \mathrm{mg} /$ day $)$ treatment was started. After 5 days of treatment, blood gas results showed improvement and treatment was discontinued. The patient was discharged from the hospital and scheduled for follow-up at the outpatient clinic.
\end{abstract}

Keywords: Sorafenib, metabolic acidosis, metastatic thyroid cancer

\section{ÖZ}

Yetmiş altı yaşında bayan hasta, metastatik papiller tiroid karsinomu tanısı ile onkoloji kliniğinde takip edilmekteydi. Vasküler endotelyal büyüme faktörü reseptörü (VEGFR) inhibitörü olan sorafenib tedavisi başlatıldı. Tedaviye başladıktan on beş gün sonra hasta yeni gelişen halsizlik, halsizlik ve bilinç bozukluğu nedeniyle acil servise başvurdu. Hastanın arteriyel kan gazı muayenesinde metabolik asidoz saptandı ve hasta iç hastalıkları kliniğine yatırıldı. Sorafenib tedavisi kesildi, ardından intravenöz sıvı ve sodyum bikarbonat tedavileri uygulandı. İdrar çıkışı ve kan gazı yakından izlendi. Ek olarak, anti-asidoz tablet (2000 mg/gün) tedavisine başlandı. 5 günlük tedaviden sonra, rutin kan gazı sonuçları iyileşme gösterdi ve tedavi kesildi. Hasta hastaneden taburcu edildi ve poliklinikte takip edilmesi planland..

Anahtar Kelimeler: Sorafenib, metabolik asidoz, metastatik tiroid kanser

\section{INTRODUCTION}

Thyroid cancer is the most common malignancy of the endocrine system and Differentiatedthyroid carcinomas usually have an excellent prognosis with 10 -year survival rates exceeding $90 \%$ to $95 \%$ Radioiodine iodine therapy becomes ineffective in $5 \%$ of cases,resulting in the development of metastasis $(1,2)$. Radioiodine iodine therapy plays an important role in the prognosis of the disease. The role of radioiodine iodine therapy in thyroid cancers is especially important for the treatment of residual tumor tissue and the prevention of metastasis. The survival rate is approximately $40 \%$ in patients with micro-metastasis $(<10 \mathrm{~mm})$, whereas it is lower in those with macro-metastasis (15\%). Distant organ metastasis develops in $15 \%-20 \%$ of patients with differentiated thyroid cancers, while lung metastasis develops in $10 \%$ of patients (3). Survival rates are even lower in patients who are refractory to radioiodine iodine therapy which has led to the emergence of new treatment models for such patients (4).Recently, sorafenib (Bayer AG D-51368 Leverkusen/Germany) has been used in patients with metastatic thyroid cancer who are resistant to radioactive iodine and doxorubicin therapies (5). Sorafenib is an anti-angiogenic tyrosine kinase inhibitor and inhibits BRAF and vascular endothelial growth factor receptors (VEGFRs) 1 and 2, which are responsible for tumor angiogenesis and tumor vascularisation (6). Sorafenib 
should be used very carefully in those who are refractory to radioactive iodine therapy due to the possibility of serious side effects, especially in the elderly patients. The most common side effects are hand-foot syndrome, rash, weight loss, diarrhea and hypertension. Rare side effects include tumor lysis syndrome and metabolic acidosis $(7,8)$. In this report, we describe a rare case of metabolic acidosis caused by sorafenib therapy.

\section{CASE REPORT}

A 76-year-old female patient was diagnosed with papillary thyroid carcinoma 2 years ago. She underwent total thyroidectomy and received radioactive radioiodine iodine therapy. Sorafenib (400 mg/day) was initiated for the treatment of lung metastasis because the tumor was refractory to iodine therapy. Fifteen days after the treatment was started, the patient was admitted to the emergency department due to weakness, fatigue and impaired consciousness.

The first laboratory tests in the emergency department were: Glucose: $82 \mathrm{mg} / \mathrm{dl}$, urea: $20 \mathrm{mg} / \mathrm{dl}$, creatinine: 0.98 $\mathrm{mg} / \mathrm{dl}, \mathrm{Na}: 138 \mathrm{mmol} / \mathrm{L}, \mathrm{K}: 4.1 \mathrm{mmol} / \mathrm{L}, \mathrm{AST}: 18 \mathrm{U} / \mathrm{L}$, ALT: $16 \mathrm{U} / \mathrm{L}$, albumin: $3.1 \mathrm{gr} / \mathrm{dl}, \mathrm{WBC}: 5860 / \mathrm{mm}^{3}$, $\mathrm{Hgb}$ : $10.2 \mathrm{~g} / \mathrm{dl}$, PLT: $146.000 / \mathrm{mm}^{3}$ (150-450), and arterial blood gas analysis were $\mathrm{pH}: 7.25, \mathrm{HCO}_{3}: 8 \mathrm{mg} / \mathrm{dl}$ (Table 1, Table2).

\begin{tabular}{|ll|}
\hline Table 1. Laboratory findings & \\
\hline Glucose & $82(70-100) \mathrm{mg} / \mathrm{dl}$ \\
Urea & $20(9.8-20) \mathrm{mg} / \mathrm{dl}$ \\
Creatine & $0.98(0.57-1.11) \mathrm{mg} / \mathrm{dl}$ \\
ALT & $16(0-55) \mathrm{U} / \mathrm{L}$ \\
$\mathrm{AST}$ & $18(5-34) \mathrm{U} / \mathrm{L}$ \\
$\mathrm{Na}$ & $138(136-145) \mathrm{mmol} / \mathrm{L}$ \\
$\mathrm{K}$ & $4.13(3.5-5.1) \mathrm{mmol} / \mathrm{L}$ \\
$\mathrm{Ca}$ & $8.2(8.4-10.6) \mathrm{mg} / \mathrm{dl}$ \\
Uric Acid & $5.86(2.6-6) \mathrm{mg} / \mathrm{dl}$ \\
Albumin & $3.1(3.5-5) \mathrm{g} / \mathrm{dl}$ \\
CRP & $1.77(0-5) \mathrm{mg} / \mathrm{dl}$ \\
Erythrocyte Sedimentation Rate & $19(0-20) \mathrm{mm} / \mathrm{h}$ \\
Hb & $10.2 \mathrm{~g} / \mathrm{L}(12-14) \mathrm{mg} / \mathrm{dl}$ \\
PLT & $146 \times 10^{3}\left(173-190 \times 10^{3}\right)$ \\
WBC & $5.860(4.490-12.680)$ \\
\hline
\end{tabular}

\begin{tabular}{|ll|}
\hline Table 2. Blood gas findings \\
\hline $\mathrm{pH}$ & $7.25(7.35-7.45)$ \\
$\mathrm{PaCO}_{2}$ & $36(35-45)$ \\
$\mathrm{PaO}_{2}$ & $88(70-100)$ \\
$\mathrm{SpO}_{2}$ & $91(95-98)$ \\
$\mathrm{HCO}_{3}$ & $\mathbf{8}(22-26)$ \\
$\% \mathrm{MetHb}$ & $1.3(<2 \%)$ \\
$\% \mathrm{COHb}$ & $2.2(<3 \%)$ \\
$\mathrm{Base}_{\mathrm{N}}$ excess & $-14(-2,+2)$ \\
$\mathrm{CaO}_{2}$ & $17(16-22)$ \\
\hline
\end{tabular}

Computed tomography of the thorax revealed multiple spherical, well-circumscribed, metastatic nodules scattered across all lobes of both lungs, the largest measuring $11 \mathrm{~mm}$ and located in the upper lobe of the right lung (Figure).

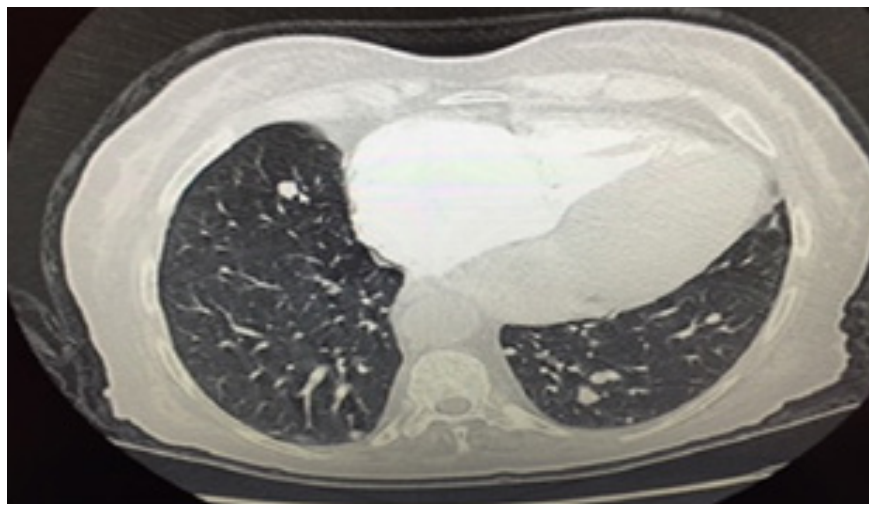

Figure. Nodular metastatic lesion measuring $11 \mathrm{~mm}$ located in the upper lobe of the right lung

Metabolic acidosis was detected on arterial blood gas analysis in the emergency department; therefore, the patient was hospitalized in. After monitoring the patient, intravenous fluid and sodium bicarbonate therapies were started. Urinary output and arterial blood gases were closely monitored. Another rare but severe side effect, sorafenib-related tumor lysis syndrome, was evaluated and ruled out. Postrenal acute kidney injury due to obstruction in the urinary tract was ruled out via renal ultrasonography. Finally, after ruling out all other causes of metabolic acidosis, sorafenib therapy was discontinued due to the suspicion of sorafenib-related metabolic acidosis. Vital signs were closely evaluated and the patient was started on a $2000 \mathrm{mg} / \mathrm{dl}$ anti-acidosis tablet in addition to the ongoing intravenous sodium bicarbonate therapy. After the 5 days of treatment, the patient's metabolic acidosis was resolved. Medical therapy was discontinued after the disappearance of symptoms such as nausea, vomiting and impaired consciousness. The patient was discharged and scheduled for a follow-up visit at the outpatient clinic. Written informed consent was obtained from the patient for the presentation.

\section{DISCUSSION}

The incidence of differentiated thyroid cancer is gradually increasing. Althoughits prognosis is generally good, patients with metastasis have higher 10-year mortality $(\geq 50 \%)$ than those without metastasis (8). Drug-related side effects generally occur in the early stages of treatment. In our case, the patient was admitted to the emergency department on day-15 of the treatment. Side effects related to sorafenib are welltolerated in young patients but are more severe in elderly 
patients, as in our case (7). Cases of metabolic acidosis caused by sorafenib therapy have been associated with tumor lysis syndrome in the literature (9). However, in our case, tumor lysis syndrome was ruled out as well as other causes of metabolic acidosis. Although the literature reports that some cases with tumor lysis syndrome showed mortal progress, our patient's metabolic acidosis resolved with prompt treatment and discontinuation of sorafenib therapy (10). We believe that the favourable prognosis of our patient can be attributed to 2 major factors: 1) the establishment of definitive diagnosis before progression to tumor lysis syndrome, and 2) early initiation treatment for side effects after discontinuation of sorafenib therapy.

\section{CONCLUSION}

Sorafenib is an oral VEGFR inhibitor used for the treatment of locally recurrent or metastatic, progressive differentiated thyroid cancer that no longer responds to radioiodine treatment. However, sorafenib therapy is associated with multiple side effects which may be fatal, particularly in the elderly patients. In the literature, tumor lysis syndrome has been reported in patients who develop side effects with sorafenib. Our patient was promptly diagnosed and treated, which may have prevented the development of tumor lysis syndrome and fatal outcome. Notably, we would like to remind clinicians that patients should be sufficiently informed about the side effects of drugs.

\section{ETHICAL DECLARATIONS}

Informed Consent: Written informed consent was obtained from all participants who participated in this study.

Referee Evaluation Process: Externally peer-reviewed.

Conflict of Interest Statement: The authors have no conflicts of interest to declare.

Financial Disclosure: The authors declared that this study has received no financial support.

Author Contributions: All of the authors declare that they have all participated in the design, execution, and analysis of the paper, and that they have approved the final version.

\section{REFERENCES}

1. Cabanillas ME, Waguespack SG, et al. Treatment with tyrosine kinase inhibitors for patients with differentiated thyroid cancer: the M. D. Anderson experience. J Clin Endocrinol Metab 2010; 95: 2588-95.
2. Marotta V, Ramundo V, Camera L, et al. Sorafenib in advanced iodine-refractory differentiated thyroid cancer: efficacy, safety and exploratory analysis of role of serum thyroglobulin and FDG-PET. Clin Endocrinol (Oxf) 2013; 78: 760-7.

3. Schlumberger MJ. Diagnostic follow-up of well-differentiated thyroid carcinoma: historical perspective and current status. J Endocrinol Invest 1999; 22: 3-7.

4. Chen L, Shen Y, Luo Q, Yu Y, Lu H, Zhu R. Response to sorafenib at a low dose in patients with radioiodine-refractory pulmonary metastases from papillary thyroid carcinoma. Thyroid 2011; 21: $119-24$.

5. Shoup M, Stojadinovic A, Nissan A, et al. Prognostic indicators of outcomes in patients with distant metastases from differentiated thyroid carcinoma. J Am Coll Surg 2003; 197: 191-7.

6. Wilhelm SM, Carter C, Tang L, et al. BAY 43-9006 exhibits broad spectrum oral antitumor activity and targets the RAF/MEK/ ERK pathway and receptor tyrosine kinases involved in tumor progression and angiogenesis. Cancer Res 2004; 64: 7099-109.

7. Chrisoulidou A, Mandanas S, Margaritidou E, et al. Treatment compliance and severe adverse events limit the use of tyrosine kinase inhibitors in refractory thyroid cancer. Onco Targets Ther 2015; 8: 2435-42.

8. Cooper DS, Doherty GM, Haugen BR,et al.Revised American Thyroid Association Management Guidelines for Patients with thyroid nodules and differentiated thyroid cancer. Thyroid 2009; 19: $1167-214$.

9. Davidson MB, Thakkar S, Hix JK, Bhandarkar ND, Wong A, Schreiber MJ. Pathophysiology, clinical consequences, and treatment of tumor lysis syndrome. Am J Med2004; 116: 546-54.

10. Huang WS, Yang $\mathrm{CH}$. Sorafenib induced tumor lysis syndrome in an advanced hepatocellular carcinoma patient. World J Gastroenterol 2009; 15: 4464-6. 